\title{
On ESP Teaching Practice in China and Suggestions for Its Improvement
}

\author{
Yan Lin ${ }^{1, ~ a}$, Yu Yuan ${ }^{1, b}$, Yuan Zhang ${ }^{1,2, c}$, Juan Liu ${ }^{1, d}$ \\ ${ }^{1}$ Shanghai International Studies University, Xianda College of Economics \& Humanities, \\ Shanghai, China \\ ${ }^{2}$ Chinese Academy of Social Sciences, Shanghai Academy, Shanghai, China \\ a1202030@xdsisu.edu.cn, ${ }^{\mathrm{b}} 0801020 @ x d s i s u . e d u . c n$ \\ c1601010@xdsisu.edu.cn, ${ }^{\mathrm{d}} 1301050 @ x d s i s u . e d u . c n$
}

Keywords: ESP; Teaching Materials; Teaching Methods; Teachers

\begin{abstract}
The purpose of the paper is to review the ESP teaching practice in China and try to propose suggestions for its improvement. It begins with a general introduction to ESP, including the definition, purpose and characteristics, followed by detailed analyses of the teaching practice from the perspectives of materials, methods and teachers, and suggestions on the improvement of the three aspects are given as well.
\end{abstract}

\section{Introduction to ESP}

The notion of English for Specific Purposes (ESP) first emerged in the 1960s, and a lot of scholars and researchers have given numerous definitions, among which the most widely accepted is proposed by Hutchinson and Waters. They define ESP as "an approach to language teaching in which as decisions as to content and method are based on the learner's reason for learning” [1] and categorize ESP into three categories, namely EST (English for Science and Technology), ESS (English for Social Science) and EBE (English for Business and Economics). In 1988, Strevens further developed the definition by claiming that ESP teaching aims at meeting the need of learners who are different in the disciplines, occupations and activities. ESP teaching includes four distinguished characteristics: 1) the purpose is to meet the specific need and requirement of learners, 2) teaching contents are relevant to specific occupations and professions, 3) lexis, syntax and semantics focus attentively on language application and 4) be in contrast with General English [2].

The definitions emphasize that learners' needs are the reasons for ESP learning and teaching, and all teaching matters are based on need analysis of learners. The paper ventures to conclude that the purpose of ESP teaching is to improve the communicative abilities for learners to work in some specific occupational and professional fields. The four distinguished characteristics differ ESP from General English, and call for innovation in teaching materials, methods and teachers, for ESP teaching has been attached great importance in recent years in China, however, the teaching effectiveness is far from satisfactory. The following part of the paper will investigate the present ESP teaching practice in China and propose suggestions for its improvement.

\section{Teaching Materials}

Teaching materials are important to any language learning and teaching, for they "provide a stimulus to learning” [3]. Teaching materials can be anything, including textbooks, handouts, videos, cassettes, slides, etc, which are used by a teacher to increase the knowledge of learners and practice the skills required by the subject syllabus. In China, the main part of ESP teaching materials is the textbooks, which mainly have two types of sources: the first type of textbooks is the ones originally imported from abroad, especially the English-speaking and education well-developed countries, such as the UK and the USA. They usually include detailed explanations and thought-provoking discussions on the subject as well as the most significant findings and trends in the field; the other 
type of textbooks is compiled by professionals at home. Both of them have strong and weak points. Though the former ones are more authentic, they are not catered for the level of Chinese students, the latter type is easy to read and seems to be better tailored for Chinese learners, however, they may be too shallow, less well structured or outdated. Textbooks from abroad and at home should be chosen carefully and whatever materials used, they should be authentic and be able to prepare learners for their future occupations and professions, for ESP teaching is in essence a simulation of the language use in a real workplace situation.

Besides, learners from different universities and colleges have different language levels, interests, and anticipations, and there is no published ESP textbook tailored for all students. In order to stimulate learning interest and genuine communication, the author suggests that ESP teachers can compile and edit school-based teaching materials for their students after doing need analysis, which includes learning needs and target situation. Before the teaching process, teachers shoulder the responsibility to anticipate learners' expectations. Target situation analysis is to analyze the communicative situation that the learners are supposed to encounter, including the social cultural environment, working environment, specific psychological situation, etc. Learners tend to respond better to the teaching materials that engaging their interest and simulating their future workplace situations. Genuine communication between the learner and teaching materials come into being after learners respond to teaching materials effectively.

\section{Teaching Methods}

\subsection{The Grammar-Translation Method}

The earliest and most widely adopted method for teaching ESP in China is called Grammar -Translation Method., which derives from the classical method of teaching Greek and Latin. The basic modes are: to analyze some grammar phenomena, to compare the usage of words and phrases, and to explain the sentence by translating it into Chinese [4].

At the very beginning of learning ESP, this method works effectively for students to learn professional words and phrases, for the students are taught in their native language of the vocabulary first and have numerous chances to translate the text sentence by sentence. However, the method also has some shortcomings. ESP teaching aims at preparing students for the language use in their future job as well as developing their comprehensive abilities that include professional ability, language ability, communication ability, etc. The Grammar- Translation method may lead to students' weak competence in the aspects mentioned above, for it is mostly teacher-centered and students accept knowledge passively.

ESP teaching emphasizes the development of students' ability to use English in practical situation which requires the comprehensive development of students' capabilities. However, in a traditional classroom with the Grammar-Translation Method, students do not have sufficient opportunities to practice, especially their oral English. Consequently, teachers adopting this method are decreasing.

\subsection{Task-Based Language Teaching (TBLT)}

The paper highly recommends an approach in teaching ESP, the Task-Based Language Teaching (TBLT), which involves the specification of a sequence of interactive tasks that are performed in the target language. Advocates of TBLT like Pica, Kanagy, and Falodun suggest that the tasks in language teaching should be goal-oriented [5], and they place high importance on the actual and active involvement of learners into the classroom. Nunan claims that tasks include target tasks and pedagogical tasks [6]. Target tasks refer to language use in different situations outside the classroom, and pedagogical tasks refer to language use in the classroom. Pedagogical tasks are the basis of target tasks, for Willis gave a definition about "task" as "the target language is used by the learner for a communicative purpose in order to achieve an outcome” [7]. Thus, it is reasonable to assume ESP teaching tasks as a reflection of real workplace activities. 
Teachers adopt TBLT in ESP teaching can include three stages in class design:

1) Pre-task: Linguistic knowledge needed for fulfilling the task, such as new words \& phrases and sentence patterns are taught to the students.

2) Task-fulfillment: Tasks are assigned to learners, and various classroom activities are employed to encourage learners to get involved, including pair work, group discussion, oral presentation, role-play, etc.

3) Task-evaluation: Task achievement is evaluated from two sides, teachers and learners. Teachers are supposed to make a conclusion and reflect future instruction, and learners should review the level of task fulfillment by summarizing their achievement and weakness.

It is suggested that TBLT should be adopted as an alternative approach to ESP teaching, for all teaching activities should be task-based, that is, to prepare learners for the communicative situation that the learners are supposed to encounter, including the social cultural environment, working environment, specific psychological situation, etc.

\section{Teachers}

In China, most ESP teachers are majored in English teaching, and have studied linguistics or literature in university. Few of them are equipped with professional knowledge and skills, let alone relevant working experience in the subject they are teaching. As a result, the mode of traditional English teaching is adopted in the teaching of ESP, which differs greatly from general English in both teaching content and purpose.

\subsection{Cooperation and Group Teaching}

Who can teach ESP? An English language teacher or a specialist has a good command of English? Stryker and Leaver suggest that ESP teachers must be more than just good language teachers; they must be knowledgeable in the subject matter and know how to elicit knowledge from their students. However, it is often difficult to find a language teacher with this combination of skills, hence, group teaching is a good choice [8]. Successful ESP teaching calls for mutual help and cooperation between General English teachers and subject teachers. English teachers better understand pedagogical theories concerning English language teaching, and subject teachers are more familiar with the subject matters and workplace situations. General English teachers help to improve the language capacity that learners need in their ESP learning, in the meanwhile, subject teachers help English teachers prepare more subject-related teaching materials and cases. Group teaching can be conducted in various ways: 1) cooperation inside class-- two teachers present at the class simultaneously, 2) cooperation outside class-only one teacher teaching at a time and teaching materials and teaching methods are prepared by two or more teachers coordinately. Whatever ways are used, coordination and communication between English language teachers and subject teachers cannot be neglected.

\subsection{Work Placement}

Most students have work placement activities, and their benefits are well recognized, however, ESP teachers in China have less contact with industries. The purpose of ESP teaching is to help students prepare themselves to communicate in English about the subject they will specialize in their future occupations and professions. Inadequate contact with the workplace leads to a result that some teachers are unable to relate textbook knowledge to real cases in workplace. Some scholars advocate that ESP teachers should have working experience to better guide students, and the Ministry of Education in China has been implementing a national training plan for ESP teachers to have work placement in companies and factories. Teachers are expected to provide lessons have workplace relevance and incorporate the latest trend and actual work situation in teaching. The author holds that a qualified ESP teacher should be able to integrate the latest professional knowledge of textbook content with the rapid development of workplace situation. For example, in Business English classes, teachers are supposed to introduce the latest cases from the Internet or 
their own experience for students to analyze and practice. Teachers who are well trained and have rich workplace experience better adopt teaching materials and methods based on their rich experience and perception of occupational needs.

\section{Conclusion}

The paper studies the practice of ESP teaching in China from the perspectives of teaching materials, teaching methods and teachers. Reasons for the unsatisfactory teaching effectiveness are various, teaching materials are outdated and not well catered for students' language level, teaching methods are dull and not innovated, and parts of teachers lack knowledge on workplace situations, etc. The author ventures to propose suggestions for the improvement of ESP teaching in China. First, authentic teaching materials from abroad and at home should be chosen and school-based materials compiled by teachers would better help learners. Innovated teaching method like Task-Based Language Teaching is suggested to be adopted as an alternative approach to better improve students' communicative competence in their future occupations and professions. Group teaching and work placement of ESP teachers are effective and feasible ways to improve their teaching competence as well as self-development. Innovation in teaching materials, methods and teachers will definitely improve the teaching effect of ESP in China.

\section{References}

[1] Hutchinson T, Waters A. English for Specific Purposes: A Learning-Centered Approach [M]. Cambridge: Cambridge University Press, 1987.

[2] Strevens P. ESP after Twenty Years: A Re-appraisal [C]. Singapore: SEAMED Regional Center, 1988.

[3] Hutchinson T, Waters A. English for Specific Purposes [M]. Shanghai: Shanghai Foreign Language Education Press, 2002.

[4] McDonough, J. ESP in Perspective: A Practical Guide [M]. London and Glasgow: Collins EST, 1984.

[5] Pica T, Kanagy R, Falodun J. Choosing and Using Communication Tasks for Second Language Instruction and Research [A]. In G. Crookes \& S. Gaas (eds.): Tasks and Language Learning: Integrating Theory and Practice. Clevedon, Avon: Multilingual Matters, 1993.

[6] Nunan, D. Understanding Language Classroom: A Guide for Teacher-initial Action [M]. Hemel Hempstead: Prentice Hall, 1989.

[7] Willis, D. A Framework for Task-Based Learning [M]. London: Longman, 1996.

[8] Stryker S, Leaver B. Content-based Instruction in Foreign Language Education: Models and Methods [M]. Washington DC: Georgetown University Press, 1997. 